sjon og energianvendelse, men disse forslagene er neppe utprøvd i kontrollerte, kliniske forsøk. Bruken av antidepressiver er omtalt, men behandlingen er ikke omtalt for andre vanlige komorbiditeter som for eksempel hjertesykdommer, diabetes mellitus, osteoporose og muskelatrofi. Jeg lar meg også overraske over omtalen av legemidler som anti-fosforesteraser som foreløpig ikke er godkjent for bruk i Norge, og av operativ lungevolumreseksjon som ikke lenger gis som et effektivt behandlingstilbud ved kols i Norge.

Heftet er lettlest, med gode forklaringer og illustrasjoner. Det kan være til praktisk hjelp for de mange med kols og bør få stor utbredelse. Det anbefales også lest av fastleger og spesialister i lungesykdommer slik at de har kunnskaper om hvilken bakgrunnsinformasjon pasientene kan ha når de kommer til konsultasjon.

\section{Amund Gulsvik}

Seksjon for lungemedisin og klinisk

respirasjonsfysiologi

Institutt for indremedisin

Universitetet i Bergen

\section{«og skulle det stundom falle litt tørt, så er det dog sant og visst»}

Kragh JV, red

Psykiatriens historie i Danmark

378 s, ill. København: Hans Reitzels Forlag, 2009. Pris DKK 348

ISBN 978-87-412-5146-2

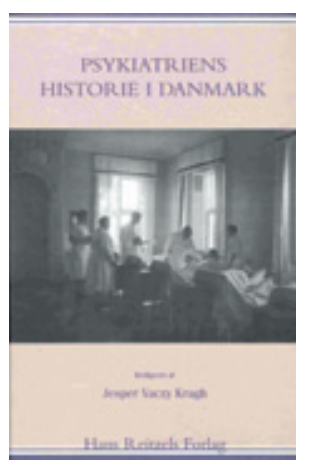

Overstående sitat fra «Terje Vigen» finner jeg dekkende som oppsummering av denne boken.

Det er forfatternes intensjon å beskrive historien til dansk hospitalpsykiatri fra 1612 og frem til i dag. Målsettingen står i innledningen: «at beskrive psy-

kiatrien ud fra den relevante historiske kontekst, fordi psykiatrien ikke kun drejer sig om læger og hospitaler. Den handler også om patienter, politikere, journalister, jurister, psykologer og andre faggrupper, der på forskjellig vis har været med til at påvirke området.» Boken lykkes bare sånn måtelig med det, siden psykologer og andre faggrupper knapt er nevnt, og den idéhistoriske kontekst gjennomgående er lite til stede. Noen målgruppe angis ikke.

Det er åtte forfattere, seks historikere og to psykiatere, alle med betydelig akademisk kompetanse, og de har skrevet hvert sitt kapitel med lite overlapping. Det legges vekt på vederheftig kildebruk og -kritikk. Layouten er leservennlig, det er godt papir og fine illustrasjoner i svart-hvitt. I historisk-filosofisk tradisjon er det 47 sider med noter bakerst. Navneregister er med, men ikke noe saksregister. For medisinere er dette litt uvant, men til å leve med.

Hva så med innholdet? At en historiker er god på kildegransking, betyr dessverre ikke at han/hun er en god, enn si, underholdende forfatter. Vi kan selvfølgelig ikke kreve at enhver historiker er Peter Englund, men kunne de enda nå ham til knes! Kapitlet om utviklingen fra Pæsthus til St. Hans Hospital, inneholder mye om arkitektur og administrasjon, men fint lite av klinisk interesse. Det samme gjelder kapitlet om overgangen fra hospital- til distriktspsykiatri. Kanskje sier disse kapitlene mest om konservatismen i befolkningen og hos politikerne $\mathrm{i}$ forhold til psykiatriske pasienter og utviklingen i psykiatrien.

Atskillig større klinisk interesse har kapitlene om asyltiden, utviklingen av en institusjon for psykisk syke kriminelle og psykiatriske trosretninger. Det er egne, og ganske detaljerte, kapitler om malariabehandlingen for dementia paralytica, sjokkbehandling med insulin og cardiazol, og bruken av de første psykofarmaka fra 1950 til 1970. Alle følger de Per Anchersens behandlingslov med en utvikling fra kritikkløs entusiasme, via verdiløshet til et begrenset evidensbasert indikasjonsområde. Om andre behandlingsforhold er boken nærmest tildekkende. Det står en halv side om lobotomi og noen få linjer om LSDbehandling. Skildringene av de store skikkelsene i dansk psykiatri er uten unntak idealiserende og idylliserende. Det står intet om de konflikter og ulykkelige skjebner deres patologiske personlighetstrekk førte med seg.

Denne holdningen står i klar kontrast til Kringlens bok om norsk psykiatri som er mye mer åpen på konflikter (1). Holder vi de to bøkene opp mot en av verdenslitteraturens storheter: Den guddommelige komedie av Dante, har den danske boken intet til felles med den. Kringlen derimot har det til felles med Dante at han er underholdende og plasserer sine fiender i helvete. For norske fagfolk byr foreliggende danske bok på lite som ikke er mer engasjerende beskrevet av Kringlen.

\section{Alv A. Dahl}

Kreftklinikken

Oslo universitetssykehus, Rikshospitalet

\section{Litteratur}

1. Kringlen E. Norsk psykiatri gjennom tidene. Oslo: Damm, 2007.

\section{Den akademiske psykologiens historie}

\author{
Saugstad P.
}

Psykologiens historie

668 s, tab, ill. Oslo: Gyldendal Akademisk, 2009.

Pris NOK 545

ISBN 978-82-05-32637-8

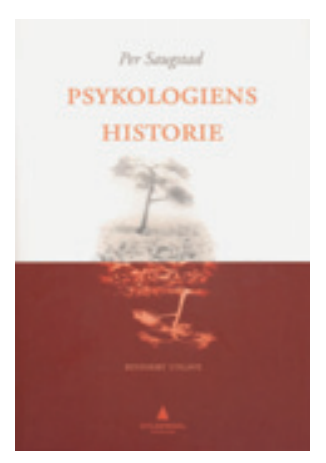

Lesingen gitt meg både gleder og savn, og det er rimelig å ta gledene først. Forfatteren er 89 år, og det er imponerende hvilken oversikt, horisont og språkføring han har, selv om dette er en revidert utgave. Dersom Eldre

lægers forening trenger dokumentasjon av intellektuell våkenhet $\mathrm{i}$ høy alder, kan den være et nyttig vedlegg!

Dette er en tykk bok (668 sider), og det fremgår ikke om det er en lære- eller oppslagsbok, eller hvem som er målgruppen. Tittelen er ambisiøs, og emnet omfattende, slik at man kan spørre seg om én forfatter kan dekke det hele. Per Saugstad velger den akademiske og overveiende empiriske psykologiens perspektiv, og han lykkes godt med det. Kombinasjonen av idéhistorie og utvikling innen de store vestlige kultur- og språkområdene er en nyttig og pedagogisk inndeling. Stundom får man følelsen av for mye «hvem ble utdannet hos hvem», slik at man savner et slags akademisk slektstre over alvorlige menn med og uten briller for å få full oversikt over «hvem er hvem» innen akademisk psykologi. Det er ingen omtale av bidrag fra skandinavisk psykologi, noe som nok hadde gitt boken økt verdi.

For en klinisk orientert anmelder blir det mye persepsjon, kognisjon, instinkt og atferd, mye basert på duer, rotter, gjess og sjimpanser. Savnet knytter seg til historien bak psykopatologi, evalueringer og terapi, selv om dette omtales innimellom. Kapitlet om psykodynamisk psykologi er ikke godt, og Freud (1856-1939) får en nokså stemoderlig behandling. Omtalen av hans samtidige Jung (1875-1961) og Adler (1870-1937) er grei nok, men jeg savner en oversikt over psykodynamikkens senere historie.

Dette bringer opp historikerens kjente dilemma om når man skal si stopp, og angi at nåtiden foreløpig unndrar seg historikerens vurdering. Saugstad er ikke helt klar på dette, til gjengjeld har han en fin balanse mellom biografisk (store menn) og narrativ (store ideer) historieskriving.

Jeg synes ikke denne boken egner seg for leger i psykiatrisk spesialistutdanning eller for ferdige spesialister i psykiatri dersom de 